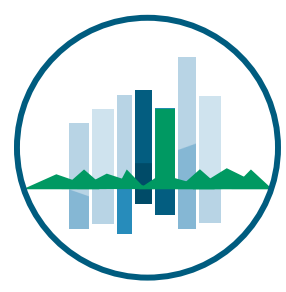

True Smart and Green City?

8th Conference of the

International Forum on Urbanism
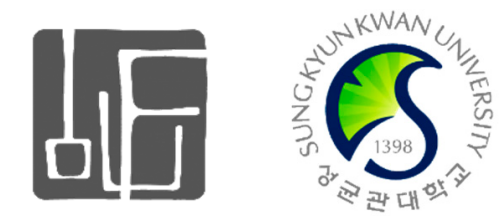

Conference Proceedings Paper

\title{
Optimal Intraurban Hierarchy of Activity Centers - a Minimized Household Travel Energy Consumption Approach
}

\author{
Yang Xie and Jie Zhang * \\ Department of Urban Planning, Tsinghua University, 100084 Beijing, China \\ * Author to whom correspondence should be addressed; Tel.: +86 01062782109 ; \\ E-mail: Zjzhangjie@tsinghua.edu.cn.
}

\begin{abstract}
An intraurban hierarchy of activity centers interconnected by non-motorized and public transportation is broadly believed to be the ideal urban spatial structure for sustainable cities. However, the proper hinterland area for centers at each level lack empirical study. Based on the concentric structure of everyday trip spaces, working centers, shopping centers and neighborhood centers are extracted from corresponding types of Point of Interest (POI) in 286 Chinese cities at the prefectural level and above. A U-shaped curve between Household Transportation Energy Consumption (HTEC) per capita and center density at each of the three levels has been found through regression analysis. An optimal intraurban hierarchy of activity centers is suggested to construct energy-efficient cities.
\end{abstract}

Keywords: intraurban hierarchy of activity centers; household travel energy consumption; center density; U-shaped curve

\section{Introduction}

One of the most important features of an urban landscape is the clustering of economic activity in many centers of different tiers $[1,2]$. This has been amply investigated at the regional level, using cities and towns as solid points and seeking their scale distribution within an interurban hierarchy [2-7]. Yet, a city should be viewed not only as a physical entity, but also as a pattern of point locations connected by flows of people, information, money and commodities, as stated in the theory of The Urban Field [8]. Just as there are systems of cities, the cities embedded in these systems are systems themselves [9]. An intraurban hierarchy of centers with different tiers requires the same attention as has been paid to studies of the interurban hierarchy. 
The spatial arrangement of intraurban centers is closely connected with individual travel behavior. A clear movement hierarchy from an individual's local stop, district center and main city center is usually followed during an individual's everyday commuting from home to city center [10] (Figure 1). It is becoming widely believed that a hierarchy of centers interconnected by non-motorized and public transportation is the ideal urban spatial structure for sustainable cities to reduce dependence on the automobile. In such a hierarchy, a center of a higher level is surrounded by several lower-level centers [11-13]. However, the proper quantifiable spatial extent for the centers at each level lacks empirical proof [14], since almost all existing work related to urban spatial structures and Household Transportation Energy Consumption (HTEC) has been limited on the binary choice between monocentricity and polycentricity. Very few studies have investigated whether a U-shape curve exists between HTEC and center density (the number of centers divided by the urbanized area). To achieve our assumptions (Part 2), centers of different levels are determined, and HTEC data is gathered with relatively reliable methods (Part 3). Regression analysis between HTEC and center density for each level is conducted to test the existence of the U-shaped curve (Part 4). Finally, some suggestions and discussion are given in Part 5.

Figure 1. Intraurban hierarchy of centers in compact cities and movement hierarchy from city center to home. From Thompson [10].
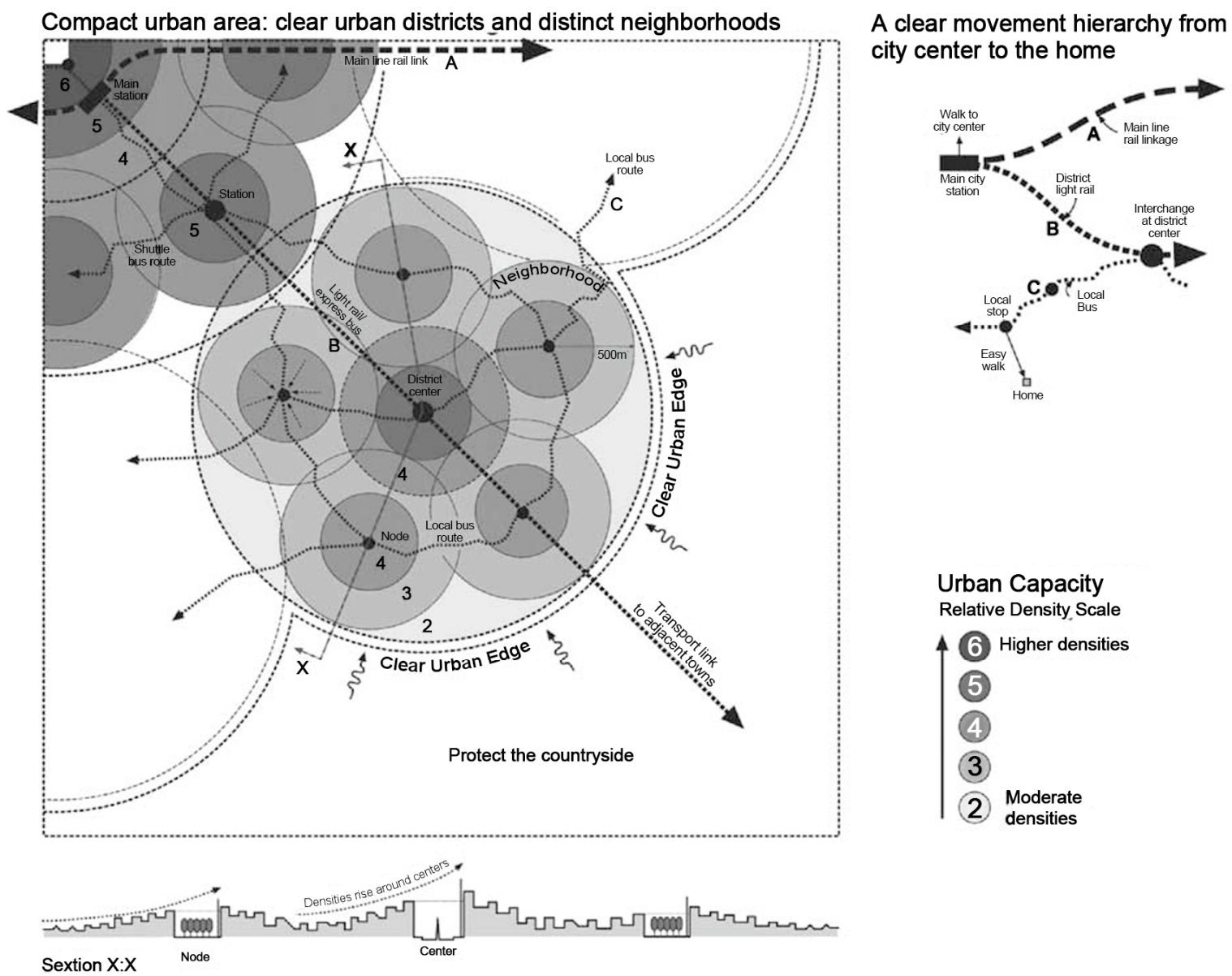

Sextion X:X Node 


\section{Literature and Assumptions}

\subsection{Intraurban hierarchy of activity centers and their spatial arrangement}

Matters and activities spatially cluster around centers of different tiers in various natural and social phenomena [3]. The same spatial patterns exist at the intraurban level $[2,4,15,16]$. Activity centers at different levels cover unique spatial extents and function with different efficient sizes [17, 18].

The proper quantifiable spatial extents for centers at each level within the intraurban hierarchy are crucial for urban planning [19]. Numerous attempts have been carried out to achieve a proper urban spatial structure throughout the twentieth century [3, 20-24]. New Urbanism, which emphasized the spatial scale of the basic development unit, has gained growing attention and support since it was proposed in the early nineteen nineties. Transit Oriented Development (TOD) advocates that a neighborhood around a public transport stop should lie within a 2000 feet (600 meter) radius, and that a higher-level development unit should be within a one mile extent [25].

Influenced by New Urbanism, more and more research has attempted to restructure spatially disordered cities by implanting non-motorized and public transportation networks. Cervero [13] advocated that dynamic second-level and third-level centers connected by multilevel transport networks should be constructed step by step in a process of urban spatial extension; in this way, an individual's need to travel to various destinations and distances would be fulfilled. Borrowing from Maslow's Hierarchy of Needs, Frey [11] demonstrated both the micro and macro spatial structures of a sustainable city with the example of Glasgow. Basically a center of a higher level is surrounded by several lowerlevel centers and all are connected by public transportation. Newman and Kenworthy [12] illustrated the intraurban hierarchy of four levels in the Sydney metropolitan area. There, the local center is the lowest level, covering an extent of three $\mathrm{km} 2$ and serving 8,000-19,000 people. The town center, the higher level, covers about $30 \mathrm{~km} 2$ and serves 70,000-175,000 people. The transit city center usually features a spatial extent of 20-30 km in radius. Finally, the Central Business District (CBD) is the highest level. Dai [26] summarized related studies on intraurban hierarchy and put forward a serious of suggestions about the scale of each level in the intraurban hierarchy for Chinese cities. However, the author himself admitted that his suggestions were based on strictly ideal assumptions that lacked of empirical study or proof. This is the common defect of all similar works.

\subsection{Concentric structure of everyday trip spaces}

The intraurban hierarchy of activity centers is closely connected with individual travel behavior [14]. Individual travel destinations (mainly shopping trips) are usually spatially distributed in a concentric structure [27-31], because preferences of travel time and mode are dissimilar for different types of activities, which can be explained by the travel time ratio (TTR) index [32,33]. The rationale behind the TTR concept is that the location where an individual will participate in an out-of-home activity is related, among other things, to the travel time investment needed to reach the activity location, as well as the duration of the activity to be conducted at that destination. Susilo and Dijst [34] used the Dutch National Travel Survey to measure the TTR index for various activities. The results show that each activity has a unique TTR index; for example, the TTR for work is about 0.12 (one hour of travel for work in accordance with an eight-hour workday). For daily product shopping, the TTR is roughly 0.4 
(a 12-minute shopping trip in accordance with 30 minutes of shopping), and it is approximately 0.23 for travel to a café/restaurant (20 minutes of travel in accordance with a 90-minute outing at the café/restaurant).

The concentric structure of everyday trip spaces is mostly investigated in terms of shopping trips. Berry and Parr [44] improved the traditional Central Place Theory by bringing in consumer behavior to explain the hierarchical structure of commercial activities. Wu et al. [35] conducted a questionnaire survey in Tianjin, discovering an obvious hierarchical structure of shopping trips, in which average shopping trips for food and vegetables is $0.4 \mathrm{~km}$, for daily necessities is $1 \mathrm{~km}$, for shirts and socks is 2 $\mathrm{km}$, for household appliances is $5 \mathrm{~km}$, and for suits and overcoats is $7.4 \mathrm{~km}$. Feng et al. [36] detected a similar concentric pattern for Beijing's residents; i.e., average shopping trips for food and vegetables is $1.07 \mathrm{~km}$, for daily necessities is $1.43 \mathrm{~km}$, for clothes is $4.04 \mathrm{~km}$, and for household appliances is $5.2 \mathrm{~km}$.

Trips for work are usually longer than for daily shopping, which can be explained by the TTR concept, since work duration greatly exceeds that of ordinary shopping activities. The constant Travel-Time Budgets (TTBs) Hypothesis is of great help in understanding individual commuting behavior. A TTB simply means that people allocate a fixed portion of the 24 hours they have in a day as the maximum amount of time out of that day that they would be willing on average to spend on travel [37]. After being first introduced by Tanner in 1961 [38], the TTB has been reported almost as a universal constant across time and space at 1-1.3 hours per person per day, e.g. 70.7 minutes [39], 70-90 minutes [40], 68 minutes [41], 78 minutes [42] and 60-80 minutes [43]. Generally, automobile and public transportation are the chief modes for commuting. Dieleman et al. [44] determined that $48 \%$ of people commute by car, and by comparison make only $30 \%$ of shopping trips by car, in the Netherlands. Zhou and Yang [45] analyzed the commuting behavior of residents in Guangzhou, China, and found that the bus is the primary mode for commuting, with $31.5 \%$ of people using it with an average commuting distance by bus of $5.5 \mathrm{~km}$. The automobile is next, with $24 \%$ with the average trip length of $4.9 \mathrm{~km}$, and the bicycle is last, with $20 \%$ using it and the average trip length is $3.0 \mathrm{~km}$.

Trips for leisure and social activities are usually longer and more automobile-dependent. According to Frandberg and Vilhelmson [46], the average trip length for visits in Sweden is $24.1 \mathrm{~km}$, and for leisure is $20.4 \mathrm{~km}$; both of these are longer than shopping trips $(9.0 \mathrm{~km})$ and work trips $(16.8 \mathrm{~km})$. Burger et al. [47] discovered that $47 \%$ of social activities and $38 \%$ of leisure activities take place out of the municipality in which one lives in Randstad, Holland. As a comparison, only 22\% of shopping activities were outside of the municipality in which an individual in Randstad lives.

\subsection{Interrelations between travel mode choice and trip distance}

With varying operational speed, accessibility, cost and comfort levels, each transport mode is suited for a unique optimal trip distance. Van Wee et al. [38] visualized the relationship between trip distance and transport mode with a theoretical model, taking the speed, cost and comfort level of different transport modes into consideration. Miao and Zhao [48] illustrated this issue similarly. Scheiner [49] reported findings from longitudinal analyses of the German national travel survey KONTIV for the period 1976-2002, and suggested that once the availability of the car is held constant, the rationale behind people's choice of travel mode for a certain trip distance remained relatively stable. It is shown that the proportion of walking is extremely high for trips shorten than $1 \mathrm{~km}$, and the proportion of 
automobile travel increases gradually for trips longer than $1 \mathrm{~km}$. The advantageous trip distance for a bicycle is $1-3 \mathrm{~km}$, and for public transport it is $5-7 \mathrm{~km}$. Liu et al. [50] built a programming model of inhabitant trip distance distribution under the constraints of various utilities; they targeted information entropy maximization and validated the model using inhabitant trip survey data from Suzhou. The result shows similar advantageous trip distance for different types of transport mode with Scheiner's study [49]. Santos et al. [51] summarized the factors that impacted the choice of transport mode, including social-economic and urban form factors, and tested them with a sample of 112 medium-sized European cities using a discrete choice modeling approach.

Detailed discussion of the advantageous trip distance of each specific transport mode is carried out by a large body of literature. Millward et al. [52] analyzed the frequency and length of walking episodes, categorized by origin, purpose, and destination, and also investigated the distance-decay function for major destinations for walking behaviors in Halifax, Canada. It was found that most walks are shorter than $600 \mathrm{~m}$, and very few exceed 1,200 m. Heinen et al. [53] summarized existing literature on commuting by bicycle, pointing out that for distances between 0.5 and $3.5 \mathrm{~km}$, the bicycle is most often used [54, 55], and noting that the 'acceptable' maximum travel distance differs between genders: 11.6 $\mathrm{km}$ for men and $6.6 \mathrm{~km}$ for women [56]. Roth et al. [14] utilized the large-scale, real-time 'Oyster' card database of individual person movements in the London subway to reveal the structure and organization of the city. It is shown that intraurban movement is strongly heterogeneous in terms of volume, but not in terms of distance travelled; an interval of 5-10 km was found to be the peak interval for subway trips. Wang et al. [57] explored the mobility patterns of passengers in a public transport network based on Shijiazhuang bus passenger survey data. The results show similar peaked distribution of travel distance, which can be fitted by a negative binomial distribution, and the peak point for a bus trip is approximately 4-5 km. Ben-Akiva and Morikawa [58] estimated models of choice among alternative travel modes using revealed preference data and stated preference data. The main conclusion is that there is no evident preference for rail travel over bus when quantifiable service characteristics such as travel time and cost are equal, but a bias does arise when rail travel offers a higher-quality service.

\subsection{Monocentricity vs. polycentricity: debate about urban spatial structure's impact on HTEC}

Large cities and urban regions are now typically described as polycentric (multi-centered), having evolved from monocentric (single-centered) entities in the presence of enhanced transport and communication technologies, rising affluence, and the decentralization of activities [1, 44, 59]. An extensive literature has developed over the last quarter century documenting relationships between travel behavior and patterns of urbanization [60-62]. However, empirical findings have been quite inconsistent about whether a monocentric or polycentric urban spatial structure tends to help reduce HTEC, as summarized by Buliung and Kanaroglou [63] in a comprehensive literature review on this issue.

Generally, the urban spatial structure impacts HTEC in two ways: one is the mode choice and the other is the travel distance and duration. Findings with respect to travel mode and polycentricity have been relatively consistent, implying that the polycentric urban form tends to be associated with higher levels of auto dependence and solo driving. This can be partially explained by (a) insufficient residenceworkplace public transit connectivity in polycentric cities and (b) discretionary activities for residents being located in peripheral and/or suburban locations [44, 64-70]. On the other hand, findings have been 
relatively inconsistent about polycentricity's impact on trip length and duration. Supporters of polycentricity use the Co-location Hypothesis to describe the potential commuting implications of firm and household decentralization. Under co-location, efficient travel is thought to emerge as firms and households follow one another during the course of employment decentralization [69, 71-75]. Supporters of monocentricity argue that even when the number of jobs and housing units in an area are equal, there is no guarantee that the people who work in an area are the same ones who live there, since a large number of empirical evidence shows that the emergence of the polycentric urban form has not led to system-wide travel efficiencies for work and other purposes [44, 64-66, 68-70]. Maat et al. [76] indicated that a commute time of 15 to 20 minutes is acceptable to many people, so they do very little to further reduce their commutes. Moreover, according to the utility theory, distance is not the only constraint on travel behavior; the benefit of shopping at a higher-quality store, for example, may outweigh distance considerations, and one might travel longer to buy better or cheaper products at a place that offers a diversity of products rather than to patronize a more limited option located nearby.

\subsection{Theoretical Assumptions}

This review of the ideal conception of the intraurban hierarchy of activity centers interconnected by non-motorized and public transportation, shows that there is a need for empirical studies on quantifiable spatial extents for centers at each level, based on the concentric structure of everyday trip spaces and the advantageous trip distance of each transport mode. As mentioned above, polycentricity is believed to be associated with higher levels of auto dependence, yet at the same time the average commuting distance may be shorter, based on the co-location hypothesis in polycentric cities. As an overlying result of both transport mode and travel distance, HTEC may feature a quadratic relationship with the average hinterland area of a center. If a center covers a vast hinterland (resembling the monocentric situation), residents at the distant periphery have to make longer commuting trips, leading to increased HTEC. On the other hand, if a center covers a small hinterland (resembling the polycentric situation), residents tend to rely on the more flexible automobile mode as a result of insufficient residence-workplace public transit connectivity. For centers at each level within the intraurban hierarchy, there may always exist a U-shaped curve between HTEC and the center density (the reciprocal of the average hinterland area of a center), implying that centers at each level have an optimal hinterland range.

The concentric structure of everyday trip spaces underlies the classification of center levels within the intraurban hierarchy. Trips conducted for daily products, kindergarten, primary school and community center are usually within a 10-minute walk (half a mile, 800 meters); i.e. this represents the first concentric layer (Neighborhood Center), resembling the concept of the Neighborhood Unit presented by Perry [23]. The main activities in the second concentric layer (Shopping Center) are nondaily shopping, service and going out for diner, most of which takes place within the desirable distance of 10-20 minute bicycling. In the third concentric layer (Working Center), companies and places of social and leisure activities such as friends' home, theaters and museums are the major destinations of individuals, and public transport (by bus or subway within the desirable time budget of 30 minutes) is the ideal mode for the third concentric layer. A U-shaped curve is assumed to exist at each of the three levels. 


\section{Methods and Data}

Theoretical assumption testing is conducted in the following three steps.

\subsection{Extraction of intraurban centers at each level}

Density thresholding based on employment is the mainstream effective method for quantitative definitions of intraurban centers [14]. Thurstain-Goodwin and Unwin [77] illustrated how to extract intraurban centers of UK towns using kernel density estimation to transform the data from point or area 'objects' into continuous surfaces of spatial densities. Following this method, we attempt to extract working, shopping and neighborhood centers of 286 Chinese cities at the prefectural level and above, based on different types of points of interest (POI) obtained from Openstreetmap1. The POIs have been supplemented and checked based on the Baidu Map2, and reclassified into the following 20 groups: Daily retail, Non-daily retail, Community center, Hotel, Restaurant, Entertainment (e.g. KTV, cinema, theater and gym), Service (e.g. barber shop, post office, telecom operator's shop, bank and 4S shop), Kindergarten, Primary school, Middle school, University and college, Research institute, Hospital, Clinic, Company, Factory, Commercial skyscraper, Residence, Government organization, and Others.

Figure 2. Exemplification of Beijing for center extractions. (Left) Raster of working facilities in Beijing. (Middle) Raster of shopping facilities in Beijing. (Right) Raster of neighborhood facilities in Beijing.
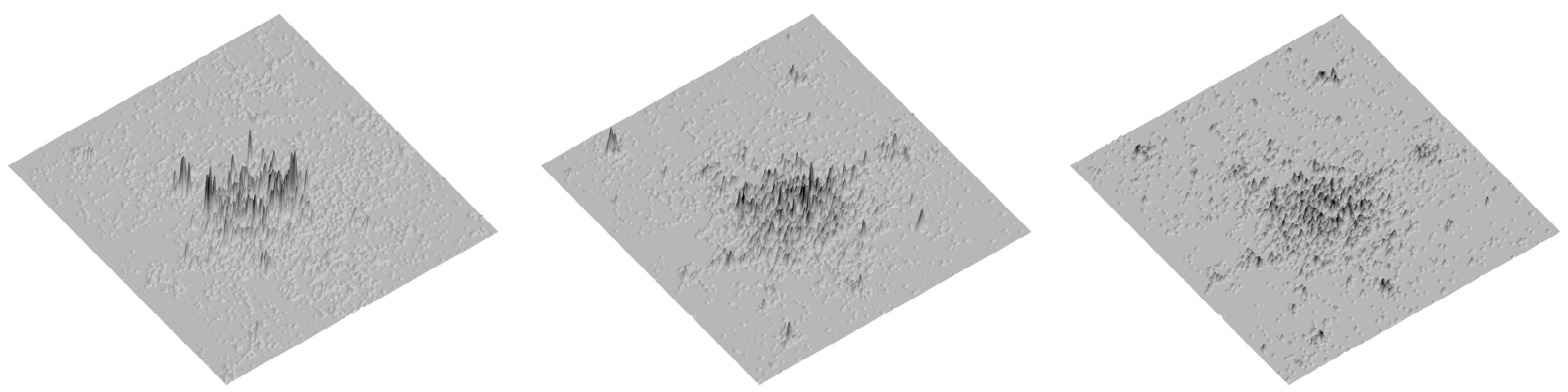

Based on the assumptions that the main activities take place in centers at each level, we extract neighborhood centers with the POIs of daily retail, community center, kindergarten, primary school and clinic (Right in Figure 2). Shopping centers are obtained with the POIs of non-daily retail, restaurant, service and middle school (Middle in Figure 2). Finally, working centers are attained with all the POIs because all the facilities generate jobs (Left in Figure 2).

Shopping centers are exemplified here to show the specific process. (1) Kernel Density Analysis with the search radius of 500 meters is utilized, sourcing from POIs of non-daily retail, restaurant, service and middle school in ArcMap 10.1. A raster with a 20-meter resolution covering the region of Mainland China is generated. (2) Urbanized areas for each city are identified based on the global urban extent map of MODIS 500 [78] and Google maps with historic versions in Google Earth 7.0. (3) A shopping

\footnotetext{
${ }^{1}$ Available at http://download.geofabrik.de/asia/china.html.

${ }^{2}$ Available at http://map.baidu.com.
} 
center raster for each city is extracted with the urbanized areas, and reclassified into ten classes based on cell value with the Natural Breaks Method3. (4) Cells in the top three classes are identified as shopping centers, after comparison with the actual location of shopping centers based on the master plans of Beijing, Shijiazhuang, Jinan, Zhengzhou, Taiyuan and so on (Figure 3).

Similarly, working centers and neighborhood centers are obtained (Figure 3). Cells in the top one class of the working center density raster are identified as working centers, while cells in the top five classes of the neighborhood center raster are recognized as neighborhood centers, after comparison with actual positions of neighborhoods based on the master plans of cities mentioned above.

Figure 3. Extraction results of working centers (upper), shopping centers (middle) and neighborhood centers (lower). Black stands for centers, red stands for cells with lower value, and blue stands for cells with higher value.
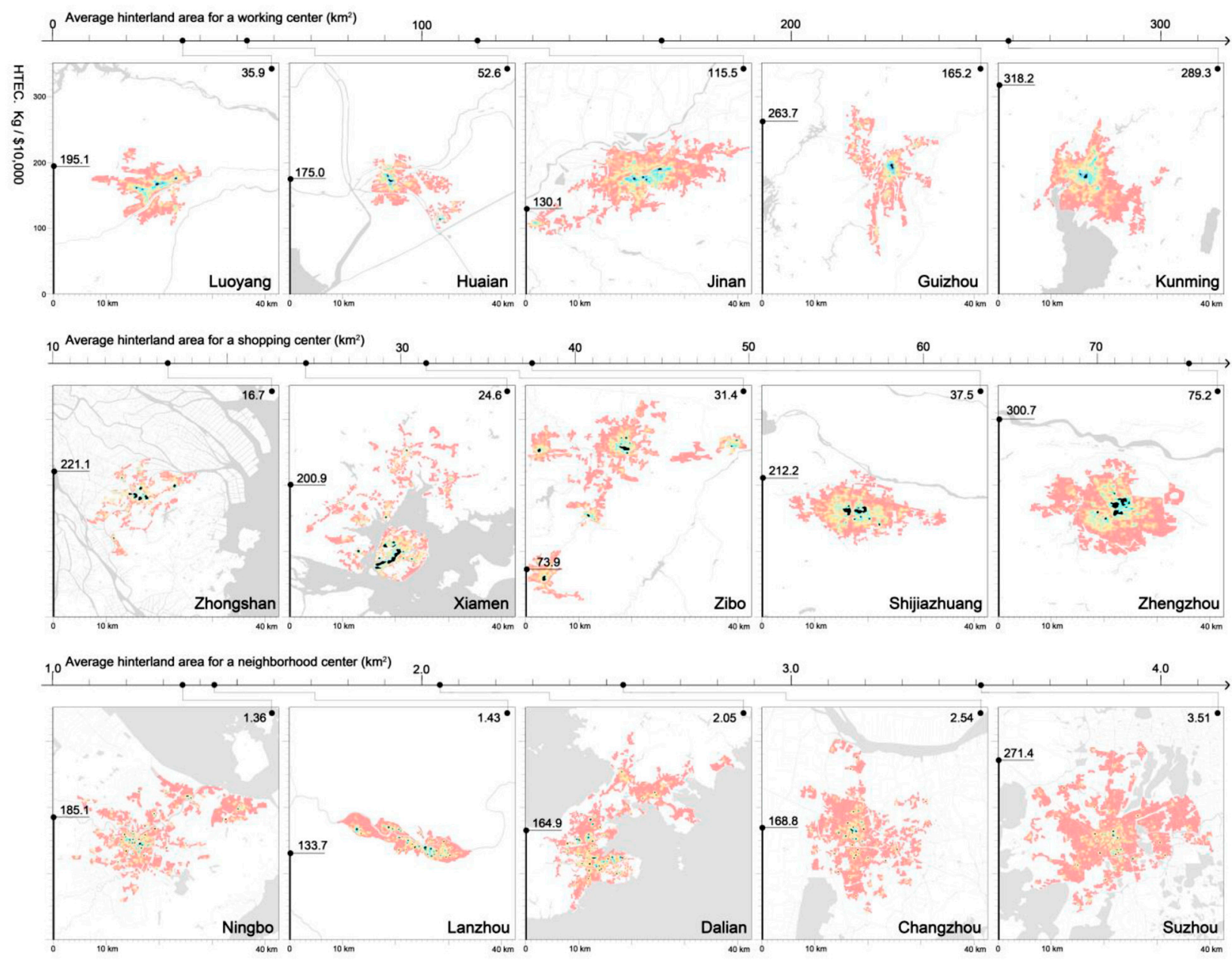

\subsection{Estimations of HTEC and obtainment of controlled variables}

HTEC per capita is estimated with the "Top-down Method" provided by the 2006 IPCC guidelines for national greenhouse gas inventories [79] as showed below.

\footnotetext{
${ }^{3}$ Natural Breaks classes are based on natural groupings inherent in the data, class breaks are identified that best group similar values and that maximize the differences between classes, from ArcGIS 10.1 Help Document, available at http://resources.arcgis.com/en/help/main/10.1/index.htm/\#//00s50000001r000000.
} 


$$
\left[\mathrm{C}=\mathrm{Q} 1 \times \mathrm{L} 1 \times \lambda 1 \times \mathrm{EF} 1 / \mathrm{P}+\mathrm{Q} 2 \times \mathrm{L} 2 \times \lambda 2 \times \mathrm{EF} 2 / \mathrm{P}+\mathrm{E} 1 \times \mathrm{EF} 2 \times \mathrm{Q} 3 / \mathrm{Q}^{\prime} 3 \times \mathrm{P}\right]
$$

$\mathrm{C}$ is HTEC per capita. Q1/Q2/Q3 is the amount of urban buses/taxis/private vehicles. Q'3 is the amount of private vehicles in the province where the city lies in. L1/L2 is the annual mileage of buses/taxis. $\lambda 1 / \lambda 2$ is the $100 \mathrm{~km}$ fuel factor of buses/taxis. EF1/EF2 is the carbon emission factor of diesel oil/gasoline. E1 is the household gasoline consumption of the province where the city lies in. $\mathrm{P}$ is the urban population.

Formula parameters are obtained from a variety of sources. They include: (1) urban buses/taxis/private vehicles counts and urban population from the China City Statistical Yearbook (2010), (2) carbon emission factor of diesel oil and gasoline from the IPCC National Greenhouse Gas Emissions Inventory Guidebook 2006, (3) household gasoline consumption at the provincial level from the China Energy Statistical Yearbook (2010), and (4) annual bus mileage is obtained from the Beijing Public Transport Group website while bus speed is set at $16 \mathrm{~km} / \mathrm{h}$ and fuel factor is $32 \mathrm{~L} / 100 \mathrm{~km}$ according to Zhang's research [80]. Taxis are assumed to utilize gasoline as no record exists in city statistical yearbooks for percentage of natural gas operated taxis. Annual taxi mileage is set at $12000 \mathrm{~km}$, and fuel factor is set at $10 \mathrm{~L} / 100 \mathrm{~km}$ according to Zhao's research [81].

GDP per capita, population density and urbanized area have been proven to feature significant impact on HTEC per capita by a large body of literature [82-88]. For our sample of 286 Chinese cities at the prefectural level and above: (1) the value of GDP per capita is from the China City Statistical Yearbook (2010); (2) the value of the urbanized area is obtained based on the global urban extent map of MODIS 500 [78] and Google maps with historic versions in Google Earth 7.0, as mentioned above; (3) the population density of the urbanized area is recalculated based on the population density map with a 100meter resolution provided by the Worldpop database4. This database was chosen because the population density values in the statistical yearbooks do not accurately reflect reality. The statistical yearbook calculation method, which divides the urban population by the area of the entire administrative district, results in a much smaller value of population density than what exists in reality, because the urbanized areas where most citizens settle are usually much smaller than the entire administrative district.

\subsection{Regression analyses between center density and HTEC}

Great divergences of city size in our 286 study cities necessitate a regression analysis conducted by grouping based on city size. According to the Notice on Adjusting Classification Standard of City Size published by the Chinese State Council5, Chinese cities are reclassified into five classes based on urban permanent resident population: small cities with a population under 500,000, medium cities with 500,000 to $1,000,000$ people, large cities with 1,000,000 to 5,000,000 people, extra-large cities with a population over 5,000,000 and megacities with over 10,000,000 people. Two adjustments are made based on the above classification: (1) the extra-large cities and megacities are merged into one class, since samples of each are too small to conduct a regression analysis. (2) Large cities are divided into two classes: one with a population of $1,000,000$ to $2,000,000$ and the other with a population of 2,000,000 to 5,000,000, because the latter class is proven to present the best comprehensive efficiency in China $[89,90]$.

\footnotetext{
${ }^{4}$ Available at http://www.worldpop.org.uk/data/summary/?contselect=Asia\&countselect=China\&typeselect=Population.

${ }^{5}$ Available at http://www.gov.cn/zhengce/content/2014-11/20/content 9225.htm.
} 
Figure 4. Illustration of the U-shaped curve between HTEC per capita and center densities at all three levels.

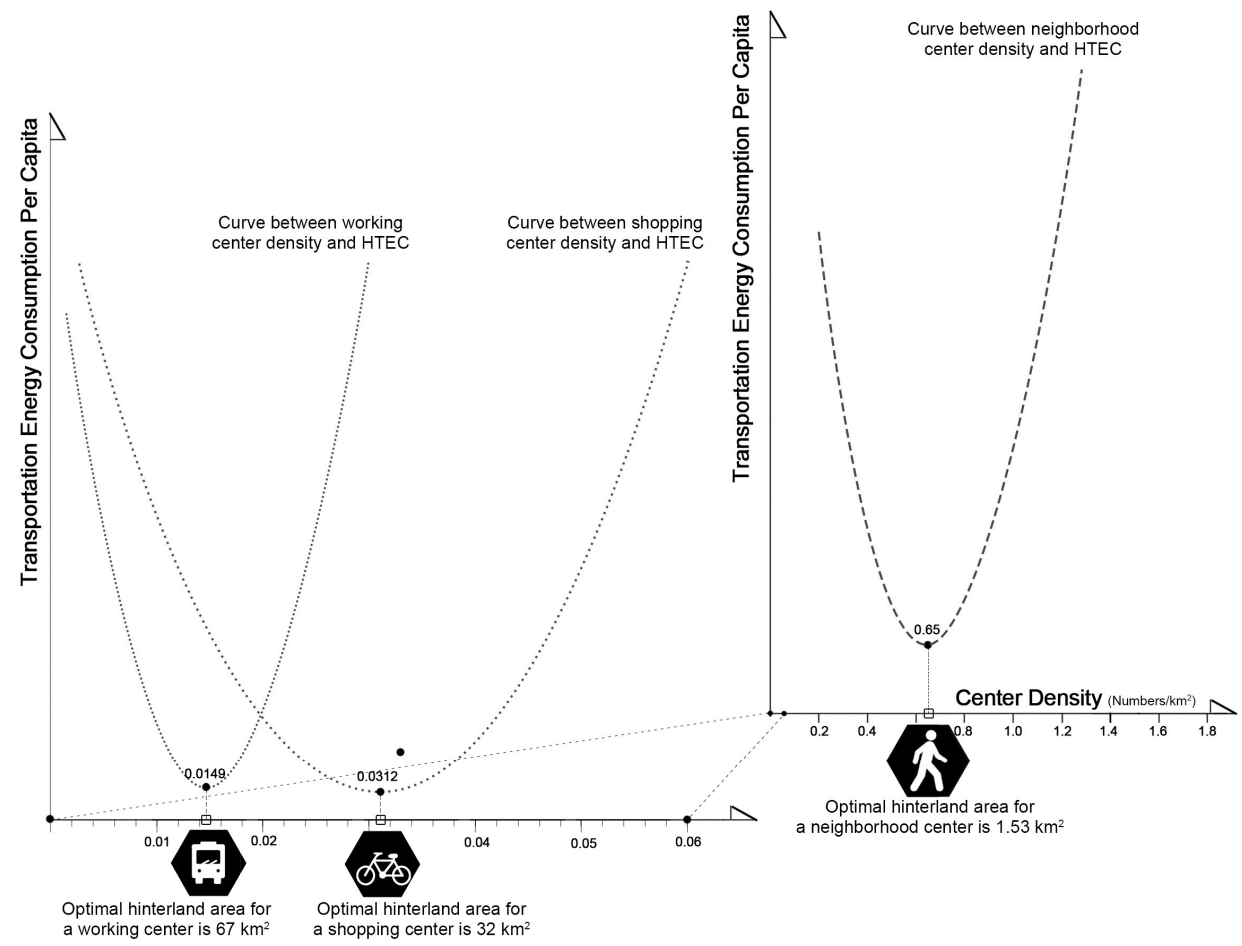

The relationship between the working center density and the natural logarithm ( $\mathrm{LN}$, used to eliminate the heteroscedasticity) of HTEC per capita is demonstrated here to exhibit the regression analysis, taking GDP per capita, population density and the urbanized area as controlled variables. A significant quadratic relationship (a U-shaped curve, as shown in Figure 4) between working center density and HTEC per capita is found only in the case of cities with a population of 2,000,000 to 5,000,000 (Table 2). Cities with working center density of 0.0149 (the average hinterland area of a working center is about $67 \mathrm{~km} 2$ ) have the lowest HTEC per capita.

Similarly, the existence of the U-shaped curve is confirmed between HTEC per capita and shopping center density in the class of a 2,000,000 to 5,000,000 population (Table 2). Cities with shopping center density of 0.0313 (the average hinterland area of a shopping center is about $32 \mathrm{~km} 2$ ) have the lowest HTEC per capita. Neighborhood center density is also demonstrated to have a significant quadratic relationship with HTEC per capita in the class of a population of 2,000,000 to 5,000,000, HTEC is the lowest for cities with neighborhood center density of 0.652 (the average hinterland area of a neighborhood center is about $1.53 \mathrm{~km} 2$ ).

It is worth mentioning that only for cities with $2,000,000$ to 5,000,000 people, three types of center densities show significant quadratic relationships with HTEC. The entire intraurban hierarchy is difficult to identify in smaller cities, while the urban spatial structure tends to be disordered and the meso-level spatial unit is generally ignored in megacities [26]. 
Table 1. Statistical description of center densities, HTEC and controlled variables.

\begin{tabular}{|c|c|c|c|c|c|}
\hline Variables & $\mathrm{N}$ & Minimum & Maximum & Average & Standard Deviation \\
\hline Working center density (numbers/km2) & 286 & 0.001 & 1.015 & 0.033 & 0.065 \\
\hline Shopping center density (numbers/km2) & 286 & 0.003 & 1.015 & 0.044 & 0.066 \\
\hline Neighborhood center density (numbers/km2) & 286 & 0.051 & 8.442 & 0.761 & 0.834 \\
\hline HTEC (kg/person) & 286 & 9.625 & 1071.632 & 139.059 & 104.606 \\
\hline GDP per capita (1,000 Dollars/person) & 286 & 0.920 & 23.412 & 6.142 & 3.823 \\
\hline Urbanized area $(\mathrm{km} 2)$ & 286 & 0.985 & 1465.684 & 109.797 & 181.142 \\
\hline Population density (People/km2) & 286 & 355.541 & 10996.613 & 4809.247 & 2216.433 \\
\hline
\end{tabular}

Table 2. Regression results for centers at each of the three levels in the group of cities with 2,000,000 to 5,000,000 people. LN HTEC per capita is the dependent variable, coefficient in the table is short for non-standardized coefficient.

\begin{tabular}{|c|c|c|c|c|c|c|c|c|c|c|c|}
\hline $\begin{array}{l}\text { Center } \\
\text { Level }\end{array}$ & R2 & $\begin{array}{r}\text { Adjusted } \\
\text { R2 }\end{array}$ & SIG & $\mathrm{N}$ & & $\begin{array}{l}\text { Quadratic term } \\
\text { of center density }\end{array}$ & $\begin{array}{r}\text { Center } \\
\text { density }\end{array}$ & $\begin{array}{r}\text { Population } \\
\text { density }\end{array}$ & $\begin{array}{r}\text { Urbanized } \\
\text { area }\end{array}$ & $\begin{array}{r}\text { GDP per } \\
\text { capita }\end{array}$ & $\begin{array}{r}\text { Consta } \\
\text { nt }\end{array}$ \\
\hline \multirow{3}{*}{$\begin{array}{l}\text { Working } \\
\text { center }\end{array}$} & \multirow{3}{*}{0.612} & \multirow{3}{*}{0.543} & \multirow{3}{*}{0.00003} & \multirow{3}{*}{34} & Coefficient & 2924.12 & -88.3636 & 0.00004 & 0.00118 & 0.06136 & 4.211 \\
\hline & & & & & sig & 0.03192 & 0.03736 & 0.26407 & 0.20459 & 0.01714 & 0 \\
\hline & & & & & $\mathrm{t}$ & 2.25811 & -2.18576 & 1.13970 & 1.29885 & 2.53432 & 9.482 \\
\hline \multirow{3}{*}{$\begin{array}{l}\text { Shopping } \\
\text { center }\end{array}$} & \multirow{3}{*}{0.578} & \multirow{3}{*}{0.500} & \multirow{3}{*}{0.00017} & \multirow{3}{*}{33} & Coefficient & 656.678 & -40.6959 & 0.00004 & 0.00138 & 0.05951 & 4.312 \\
\hline & & & & & sig & 0.05318 & 0.03568 & 0.31484 & 0.12967 & 0.02018 & 0 \\
\hline & & & & & $\mathrm{t}$ & 2.02203 & -2.21121 & 1.02417 & 1.56314 & 2.46863 & 10.42 \\
\hline \multirow{3}{*}{$\begin{array}{l}\text { Neighbor } \\
\text { hood } \\
\text { center }\end{array}$} & \multirow{3}{*}{0.484} & \multirow{3}{*}{0.389} & \multirow{3}{*}{0.00209} & \multirow{3}{*}{33} & Coefficient & 1.85298 & -2.41565 & 0.00003 & 0.00160 & 0.03403 & 4.312 \\
\hline & & & & & sig & 0.07369 & 0.09622 & 0.47224 & 0.07356 & 0.22597 & 0 \\
\hline & & & & & $\mathrm{t}$ & 1.86080 & -1.72360 & 0.72906 & 1.86171 & 1.23911 & 10.42 \\
\hline
\end{tabular}

\section{Results and Discussion}

\subsection{Neighborhood center and HTEC}

It has been proven by the previously discussed regression analysis that a neighborhood center covering an average of $1.53 \mathrm{~km} 2$ favors reducing HTEC. Hinterlands for centers of small scale within city borders tend to be quadrangular rather than hexagonal, as typically described in the Central Place Theory, since the isochrones starting from any point in grid cities are mostly quadrangular at 45-degree angles to the grid [91] (Figure 5). We can see that the distance from the centroid (a neighborhood center) to a vertex is about 880 meters for a square of $1.53 \mathrm{~km} 2$ (Figure 4), meaning that any point within the square is less than 880 meters away from the neighborhood center. This hinterland range resembles the Neighborhood Unit of a half-mile radius presented by Perry [23]. High accessibility of daily products and services within 800 meters (a 10-minute walk) has been proven to significantly lower the HTEC per capita by encouraging non-commuting trips on foot [82, 83, 85]. A desirable distance of less than 800 meters for walking determines that some residents in a neighborhood unit larger than $1.53 \mathrm{~km} 2$ have to drive to obtain daily products; on the other hand, incomplete facilities in centers smaller than $1.53 \mathrm{~km} 2$ would also force residents to drive to centers at a higher level to find the products they need.

\subsection{Shopping center and HTEC}

From the regression analysis discussed above, we find that $32 \mathrm{~km} 2$ is the optimal hinterland area of a shopping center for the purpose of the lowest HTEC. It can be concluded that the shape of the optimal shopping center's hinterland is a square, resembling the optimal neighborhood unit described above, but about five times larger, since the distance from the centroid to a vertex for the optimal shopping center's 
hinterland ( $4 \mathrm{~km} 2)$ is about 5 times that of the optimal neighborhood center's hinterland $(0.88 \mathrm{~km} 2)$. In such a hinterland, any point is within $4 \mathrm{~km}$ distance, starting from the centroid (the shopping center); this is close to the upper limit of the desirable trip distance using the bicycle mode [54, 55]. A shopping center with a larger hinterland will mean that some residents in the periphery have to drive or take the bus to the shopping center, which is more energy-consuming than if they could travel by bicycle. Also, sometimes the products and services available at a shopping center with a smaller hinterland are undesirable, causing residents to make trips to centers at higher levels that are farther away.

\subsection{Working center and HTEC}

For working centers, the ideal hinterland area is $67 \mathrm{~km} 2$, exactly two times of that for shopping centers. According to Berry and Parr [92], the ratio $(\mathrm{k})$ of the hinterland area between one level and the lower level may be two, four or nine (Figure 5) in quadrangular central place systems. Based on the situation of $\mathrm{k}=2$, the hinterland for a working center would be a square of $8.2 \mathrm{~km}$ per side parallel to the road grid, the vertex of which is located within a shopping center. Residents in such a working center's hinterland would travel at most $5.7 \mathrm{~km}$ to the working center, which is still in the desirable distance range of buses, since none of the 35 Chinese cities with 2,000,000 to 5,000,000 people in our sample featured a subway system in 2010 (the base year of the regression). This conclusion suggests that for cities featuring faster public transport systems, e.g. subway or suburban railway, the optimal hinterland of a working center may be larger, which calls for further investigation with samples all around the globe because the number of cities featuring subway or suburban railways in any single country is too small to conduct a proper regression analysis.

\section{Conclusions}

Numerous attempts have been carried out since Howard's Garden City Theory in 1898 to achieve a proper urban spatial structure. An ideal intraurban hierarchy of activity centers interconnected by nonmotorized and public transport for sustainable cities has been proposed, conceived and advocated many times, yet the proper quantifiable spatial extents for centers at each level in terms of controlling HTEC still lack empirical proof. Based on the concentric structure of everyday trip spaces, working centers, shopping centers and neighborhood centers are extracted from corresponding types of POIs in 286 Chinese cities at the prefectural level and above. The U-shaped curve between HTEC per capita and the center density in each of the three levels has been found through regression analysis. For the purpose of achieving the lowest HTEC per capita, the optimal hinterland area is $67 \mathrm{~km} 2$ for a working center with the bus as the preferred transport mode, $32 \mathrm{~km} 2$ for a shopping center with the bicycle as the preferred transport mode, and $1.53 \mathrm{~km} 2$ for a neighborhood center with walking as the preferred transport mode (Figure 6). Thus, an optimal intraurban hierarchy of activity centers emerges, yet probable centers at higher levels in larger cities calls for further investigation from a global perspective. 
Figure 5. (Left) Isochrones starting from a neighborhood center in grid cities, speed for nonroad area is set as half of that for road, and the distance between road axes is set as 100 meters. (Right) Alternative cases of Christaller-type systems with square spacing of producers, from Berry and Parr [92].
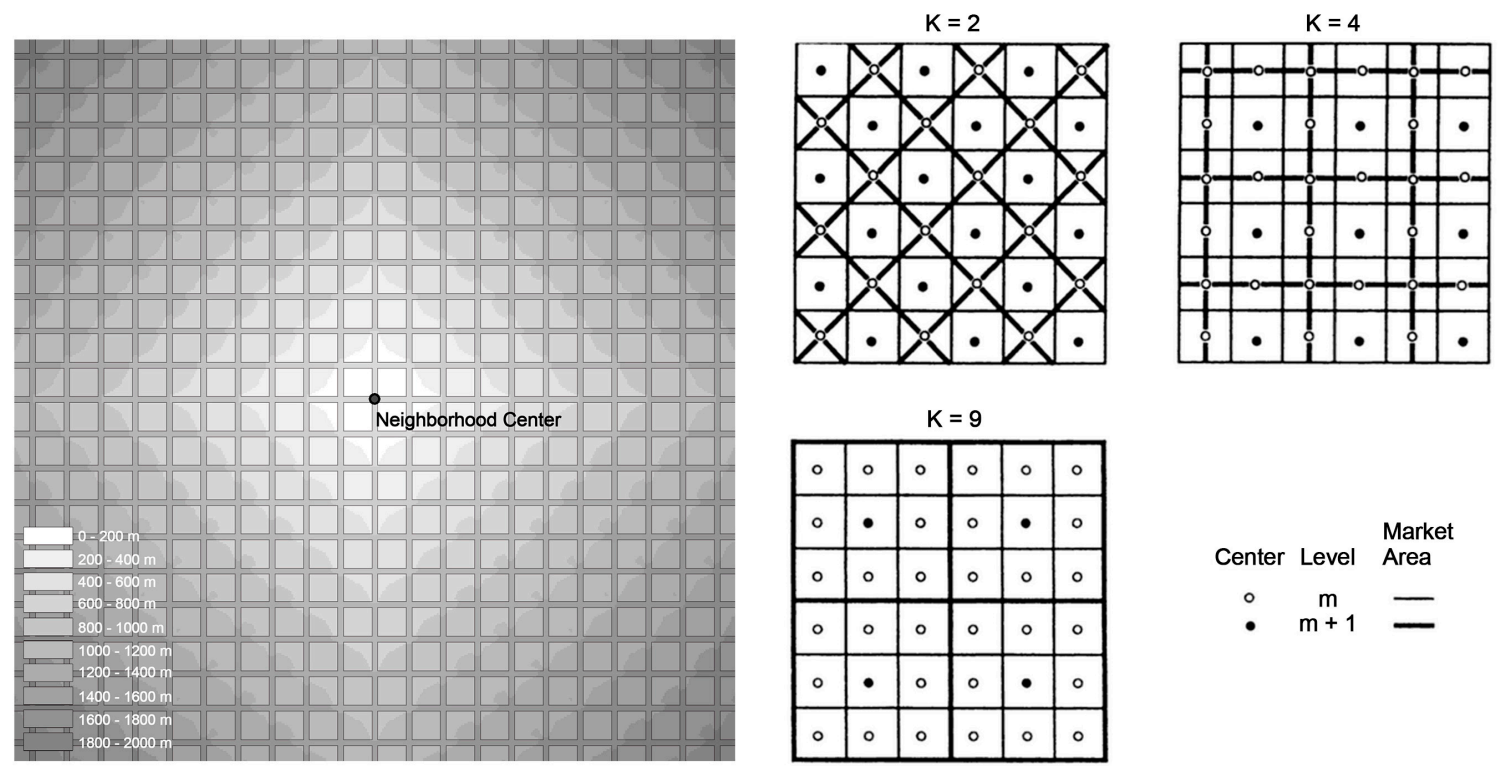

Figure 6. Illustration of the optimal intraurban hierarchy of activity centers tested in this article.

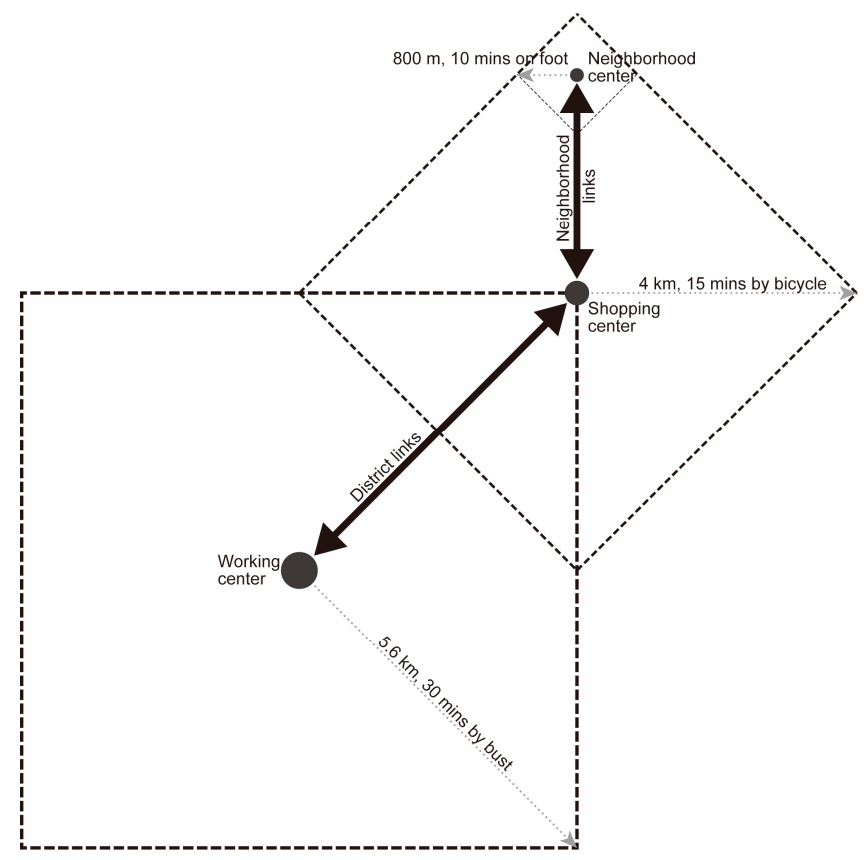




\section{Acknowledgments}

This work was supported by the following research projects: Form and Design of Energy-efficient Neighborhood in Megacities in Southern Region of North China funded by Independent Research Program of Tsinghua University (No. 2011THZ0); Low Carbon Urban Design-From Options Assessment to Policy Implementation funded by the Low Carbon Energy University Alliance (No. 2011LC002).

\section{Conflict of Interest}

The authors declare no conflict of interest.

\section{References}

1. Anas, A.; Arnott, R.; Small, K.A. Urban spatial structure. Journal of Economic Literature 1998, 36(3), 1426-1464.

2. Batty, M. The size, scale, and shape of cities. Science 2008, 319(5864), 769-771.

3. Christaller, W. Central places in southern Germany, English translation by C.W. Baskin 1966; Prentice-Hall: London, UK, 1933.

4. Batty, M.; Longley, P.A. Fractal cities: a geometry of form and function; Academic Press: Waltham, Massachusetts, USA, 1994.

5. Beckmann, M.J. City hierarchies and the distribution of city size. Economic Development and Cultural Change 1958, 6(3), 243-248.

6. Carroll, G.R. National city-size distributions what do we know after 67 years of research? Progress in Human Geography 1982, 6(1), 1-43.

7. Bettencourt, L.M.A. The origins of scaling in cities. Science 2013, 340(6139), 1438 -1441.

8. Friedmann, J.; Miller, J. The urban field. Journal of the American institute of Planners 1965, 31(4), 312-320.

9. Berry, B.J. Cities as systems within systems of cities. Papers in Regional Science 1964, 13(1), 147163.

10. Thompson, C.W. Urban open space in the 21st century. Landscape and Urban Planning 2002, 60(2), $59-72$.

11. Frey, H. Designing the city: towards a more sustainable urban form; E. \& F. N. Spon: London, UK, 1999.

12. Newman, P.; Kenworthy, J. Urban design to reduce automobile dependence. Opolis: An International Journal of Suburban and Metropolitan Studies 2006, 2(1).

13. Cervero, R. The transit metropolis: a global inquiry; Island press: Washington, DC, USA, 1998.

14. Roth, C.; Kang, S.M.; Batty, M.; Barthélemy, M. Structure of urban movements: polycentric activity and entangled hierarchical flows. PLoS ONE 2011, 6(1), e15923.

15. Batty, M. Cities and complexity: understanding cities with cellular automata, agent-based models, and fractals; The MIT press: Cambridge, Massachusetts, USA, 2007.

16. Zhou, G.Z. City and Region: a typical open giant complex system. City Planning Review 2002(02), 7-8+18 (in Chinese). 
17. Richardson, H.W. Optimality in city size, systems of cities and urban policy: a sceptic's view. Urban Studies 1972, 9(1), 29 -48.

18. Capello, R.; Camagni, R. Beyond optimal city size: An evaluation of alternative urban growth patterns. Urban Studies 2000, 37(9), 1479 -1496.

19. Mulligan, G.F.; Partridge, M.D.; Carruthers, J.I. Central place theory and its reemergence in regional science. The Annals of Regional Science 2012, 48(2), 405-431.

20. Doxiades, K.A. Ekistics: An introduction to the science of human settlements; Hutchinson: London, UK, 1968.

21. Howard, E. To-morrow: A peaceful path to real reform (new ed. 2003); Routledge: London, UK, 1898.

22. Krier, L.A.C.M. Rational architecture: the reconstruction of the European city; Archives d'architecture moderne: Brussels, Belgium, 1978.

23. Perry, C.A. The Neighborhood Unit, in Regional survey of New York and its environs; Committee on the Regional Plan of New York and Its Environs: New York, USA, 1929, pp. 34-35.

24. Hall, P.; Ward, C. Sociable cities: the legacy of Ebenezer Howard; Wiley: Chichester, UK, 1998.

25. Calthorpe, P. The next American metropolis: Ecology, community, and the American dream; Princeton Architectural Press: New York, USA, 1993.

26. Dai, D.S. Study on the hierarchial system of urban space and the pattern of development based on green transportation; Doctoral dissertation, 2011, Southeast University: Nanjing, China.

27. Chai, Y.W.; Shang, Y.R. The study on the temporal-spatial characteristics of the consumer activities of Shenzhen residents at night. Geographical Research 2005(05), 803-810 (in Chinese).

28. WANG, D.; ZHANG, J.Q. Characteristics of consumers' travel behaviour and commercial spatial structure. City Planning Review 2001(10), 6-14 (in Chinese).

29. Yao, C.J.; Chai, Y.W. The characteristic of transportation mode in resident's travel for buying highclass clothes in Shanghai. Areal Research and Development 2007(03), 45-50 (in Chinese).

30. Zhou, S.H.; Lin, G.; Yan, X.P. The relationship among consumer's travel Behavior, Urban commercial and residential spatial structure in Guangzhou, China. Acta Geographica Sinica 2008(04), 395-404 (in Chinese).

31. Ma, Y. The characteristics of shopping behaviors of Urumqi residents. Yunnan Geographic Environment Research 2008(03), 94-98 (in Chinese).

32. Dijst, M.; Vidakovic, V. Travel time ratio: the key factor of spatial reach. Transportation 2000, 27(2), 179-199.

33. Schwanen, T.; Dijst, M. Travel-time ratios for visits to the workplace: the relationship between commuting time and work duration. Transportation Research Part A: Policy and Practice 2002, 36(7), 573-592.

34. Susilo, Y.O.; Dijst, M. How far is too far? Travel time ratios for activity participations in the Netherlands. Transportation Research Record: Journal of the Transportation Research Board 2009, 2134(1), 89-98.

35. Wu, Z.Q.; Chai, Y.W.; Dai, X.Z.; Yang, W. On hierarchy of shopping trip space for urban residents: A case study of Tianjing City. Geographical Research, 2001(04), 479-488 (in Chinese).

36. Feng, J.; Chen, X.; Lan, Z. The evolution of spatial structure of shopping behaviors of Beijing's residents. Acta Geographica Sinica 2007, 62(10), 1083-1096 (in Chinese). 
37. Ahmed, A.; Stopher, P. Seventy minutes plus or minus $10-$ a review of travel time budget studies. Transport Reviews 2014, 34(5), 607-625.

38. van Wee, B.; Rietveld, P.; Meurs, H. Is average daily travel time expenditure constant? In search of explanations for an increase in average travel time. Journal of transport geography 2006, 14(2), 109-122.

39. Hupkes, G. The law of constant travel time and trip-rates. Futures 1982, 14(1), 38-46.

40. Ausubel, J.H.; Marchetti, C.; Meyer, P.S. Toward green mobility: the evolution of transport. European Review 1998, 6(02), 137-156.

41. Schafer, A.; Victor, D.G. The future mobility of the world population. Transportation Research Part A: Policy and Practice 2000, 34(3), 171-205.

42. Vilhelmson, B. Daily mobility and the use of time for different activities. The case of Sweden. GeoJournal 1999, 48(3), 177-185.

43. Metz, D. The myth of travel time saving. Transport Reviews 2008, 28(3), 321-336.

44. Dieleman, F.M.; Dijst, M.; Burghouwt, G. Urban form and travel behaviour: micro-level household attributes and residential context. Urban Studies 2002, 39(3), 507-527.

45. Zhou, S.H.; Yang, L.J. On spatial characteristics of commuting space for residents in Guangzhou, China. Urban Transport of China 2005(01), 62-67 (in Chinese).

46. Frändberg, L.; Vilhelmson, B. More or less travel: personal mobility trends in the Swedish population focusing gender and cohort. Journal of Transport Geography 2011, 19(6), 1235-1244.

47. Burger, M.J.; Van der Knaap, B.; Wall, R.S. Polycentricity and the multiplexity of urban networks. European Planning Studies 2014, 22(4), 816-840.

48. Miao, S.M.; Zhao, Y. Theory and mode of moderate development for travelling by bicycle. City Planning Review 1995(04), 41-43 (in Chinese).

49. Scheiner, J. Interrelations between travel mode choice and trip distance: trends in Germany 1976 2002. Journal of Transport Geography 2010, 18(1), 75-84.

50. Liu, J.J.; Xiao, M.D.; Wang, W. Models of inhabitant trip distance distribution based on utility and information entropy; in Proceedings of International Conference on Engineering and Business Management (EBM2010); 2010, International Conference on Engineering and Business Management (EBM2010): Chengdu, China.

51. Santos, G.; Maoh, H.; Potoglou, D.; von Brunn, T. Factors influencing modal split of commuting journeys in medium-size European cities. Journal of Transport Geography 2013, 30, 127-137.

52. Millward, H.; Spinney, J.; Scott, D. Active-transport walking behavior: destinations, durations, distances. Journal of transport geography 2013, 28, 101-110.

53. Heinen, E.; van Wee, B.; Maat, K. Commuting by bicycle: an overview of the literature. Transport reviews 2010, 30(1), 59-96.

54. Keijer, M.J.N.; Rietveld, P. How do people get to the railway station? The Dutch experience. Transportation Planning and Technology 2000, 23(3), 215-235.

55. Rietveld, P. The accessibility of railway stations: the role of the bicycle in The Netherlands. Transportation Research Part D: Transport and Environment 2000, 5(1), 71-75.

56. Howard, C.; Burns, E.K. Cycling to work in Phoenix: route choice, travel behavior, and commuter characteristics. Transportation Research Record: Journal of the Transportation Research Board 2001, 1773(1), 39-46. 
57. Wang, M.S.; Huang, L.; Yan, X.Y. Exploring the mobility patterns of public transport passengers. Journal of University of Electronic Science and Technology of China 2012(01), 2-7 (in Chinese).

58. Ben-Akiva, M.; Morikawa, T. Comparing ridership attraction of rail and bus. Transport Policy 2002, 9(2), 107-116.

59. Sun, B.D.; Pan, X. Progress in urban spatial structure's impact on travel: the debate between monocentricity and polycentricity. Urban Problems 2008(01), 19-22+28 (in Chinese).

60. Anderson, W.P.; Kanaroglou, P.S.; Miller, E.J. Urban Form, Energy and the Environment: A Review of Issues, Evidence and Policy. Urban Studies 1996, 33(1), 7 -35.

61. Badoe, D.A.; Miller, E.J. Transportation - land-use interaction: empirical findings in North America, and their implications for modeling. Transportation Research Part D: Transport and Environment 2000, 5(4), 235-263.

62. Crane, R. The influence of urban form on travel: An interpretive review. Journal of Planning Literature 2000, 15(1), 3 -23.

63. Buliung, R.N.; Kanaroglou, P.S. Urban form and household activity - Travel behavior. Growth and Change 2006, 37(2), 172-199.

64. Schwanen, T.; Dieleman, F.M.; Dijst, M. Travel behaviour in Dutch monocentric and polycentric urban systems. Journal of Transport Geography 2001, 9(3), 173-186.

65. Cervero, R.; Wu, K.L. Polycentrism, commuting, and residential location in the San Francisco Bay area. Environment and Planning A 1997, 29(5), 865-886.

66. Cervero, R.; Wu, K.L. Sub-centring and commuting: evidence from the San Francisco Bay area, 1980-90. Urban studies 1998, 35(7), 1059-1076.

67. Modarres, A. Polycentricity and transit service. Transportation Research Part A: Policy and Practice 2003, 37(10), 841-864.

68. Schwanen, T.; Dieleman, F.M.; Dijst, M. Car use in Netherlands daily urban systems: Does polycentrism result in lower commute times? Urban geography 2003, 24(5), 410-430.

69. Schwanen, T.; Dieleman, F.M.; Dijst, M. The impact of metropolitan structure on commute behavior in the Netherlands: a multilevel approach. Growth and Change 2004, 35(3), 304-333.

70. Naess, P.; Sandberg, S.L. Workplace location, modal split and energy use for commuting trips. Urban Studies 1996, 33(3), 557-580.

71. Gordon, P.; Richardson, H.W. Are compact cities a desirable planning goal? Journal of the American Planning Association 1997, 63(1), 95-106.

72. Gordon, P.; Kumar, A.; Richardson, H.W. Congestion, changing metropolitan structure, and city size in the United States. International Regional Science Review 1989, 12 (1), 45 -56.

73. Gordon, P.; Richardson, H.W.; Jun, M. The commuting paradox evidence from the top twenty. Journal of the American Planning Association 1991, 57(4), 416-420.

74. Levinson, D.M. Accessibility and the journey to work. Journal of Transport Geography 1998, 6(1), 11-21.

75. Levinson, D.M.; Kumar, A. The rational locator: Why travel times have remained stable. Journal of the American Planning Association 1994, 60(3), 319-332.

76. Maat, K.; Van Wee, B.; Stead, D. Land use and travel behaviour: expected effects from the perspective of utility theory and activity-based theories. Environment and Planning B: Planning and Design 2005, 32, 33-46. 
77. Thurstain Goodwin, M.; Unwin, D. Defining and delineating the central areas of towns for statistical monitoring using continuous surface representations. Transactions in GIS 2000, 4(4), 305-317.

78. Schneider, A.; Friedl, M.A.; Potere, D. A new map of global urban extent from MODIS satellite data. Environmental Research Letters 2009, 4(4), 044003.

79. Eggleston, H.S.; Buendia, L.; Miwa, K.; Ngara, T.; Tanabe, K. IPCC guidelines for national greenhouse gas inventories; Institute for Global Environmental Strategies (IGES): Hayama, Japan, 2006.

80. Zhang, Y.; Qin, Y.C.; Yan, W.Y.; Zhang, J.P.; Zhang, L.J.; Lu, F.X.; Wang, X. Urban types and impact factors on carbon emissions from direct energy consumption of residents in China. Geographical Research 2012, 31(2), 345-356 (in Chinese).

81. Zhao, M.; Zhang, W.G.; Yu, L.Z. Resident travel modes and CO2 emissions by traffic in Shanghai City. Research of Environmental Sciences 2009, 22(6), 747-752 (in Chinese).

82. Cervero, R.; Kockelman, K. Travel demand and the 3Ds: density, diversity, and design. Transportation Research Part D: Transport and Environment 1997, 2(3), 199--219.

83. Handy, S.L.; Boarnet, M.G.; Ewing, R.; Killingsworth, R.E. How the built environment affects physical activity: Views from urban planning. American Journal of Preventive Medicine 2002, 23(2, Supplement 1), 64-73.

84. Saelens, B.E.; Sallis, J.F.; Frank, L.D. Environmental correlates of walking and cycling: Findings from the transportation, urban design, and planning literatures. Annals of Behavioral Medicine 2003, 25(2), 80-91.

85. Ewing, R.; Cervero, R. Travel and the built environment. Journal of the American Planning Association 2010, 76(3), 265-294.

86. Glaeser, E.L.; Kahn, M.E. The greenness of cities: carbon dioxide emissions and urban development. Journal of urban economics 2010, 67(3), 404-418.

87. Oliveira, E.A.; Andrade Jr, J.E.S.; Makse, H.A.N.A. Large cities are less green. Scientific reports 2014, 4. DOI: 10.1038/srep04235.

88. Louf, R.; Barthelemy, M. How congestion shapes cities: from mobility patterns to scaling. Scientific Reports 2014, 4. DOI: 10.1038/srep05561.

89. Wang, X.L.; Xia, X.L. Optimizing city size and promoting economic growth. Economic Research Journal 1999(09), 22-29 (in Chinese).

90. Wang, X.L. Urbanization path and city scale in China: an economic analysis. Economic Research Journal 2010(10), 20-32 (in Chinese).

91. Hoover, E.M. An introduction to regional economics; Alfred A. Knopf: New York, USA, 1971.

92. Berry, B.J.; Parr, J.B. Market centers and retail location: Theory and Applications; Prentice Hall: Englewood Cliffs, New Jersey, USA, 1988.

(C) 2015 by the authors; licensee MDPI and IFoU, This article is an open access article distributed under the terms and conditions of the Creative Commons Attribution license. 